\title{
Hubungan antara Riwayat Status Gizi Ibu Masa Kehamilan dengan Pertumbuhan Anak Balita di Kecamatan Soreang Kabupaten Bandung
}

\author{
Ridha Mustika Zaif', Merry Wijaya², Dany Hilmanto ${ }^{3}$ \\ ${ }^{1}$ Fakultas Kedokteran Universitas Padjadjaran \\ ${ }^{2}$ Departemen Ilmu Kesehatan Masyarakat, Fakultas Kedokteran Universitas Padjadjaran \\ ${ }^{3}$ Departemen Ilmu Kesehatan Anak, Fakultas Kedokteran Universitas Padjajaran / Rumah Sakit Umum Pusat \\ Dr. Hasan Sadikin, Bandung, Indonesia
}

\begin{abstract}
Abstrak
Pertumbuhan saat balita memiliki dampak terhadap kehidupan selanjutnya karena masa balita merupakan masa kritis (golden period). Status gizi anak harus diperhatikan sejak dalam kandungan. Asupan gizi yang baik pada saat kehamilan penting untuk pertumbuhan janin sampai bayi dilahirkan. Bayi lahir dengan berat badan rendah dapat mengalami risiko gangguan pertumbuhan dengan gizi kurang, pendek dan kurus. Penelitian ini bertujuan untuk mengetahui hubungan riwayat status gizi ibu masa kehamilan yang dinilai dengan pertambahan berat badan ibu trimester III dan ukuran LILA dengan pertumbuhan balita. Desain penelitian dengan cross sectional. Jumlah sampel sebanyak 109 ibu yang mempunyai balita di Kecamatan Soreang, Kabupaten Bandung pada bulan MaretNovember 2016. Pengambilan sample dengan multistage random sampling dan dianalisis dengan uji Gamma Chisquare. Tidak terdapat hubungan antara lingkar lengan atas (LILA) ibu saat hamil dengan pertumbuhan anak balita berdasarkan $\mathrm{BB} / \mathrm{U}(\mathrm{p}=0,065), \mathrm{TB} / \mathrm{U}(\mathrm{p}=0,218)$ dan $\mathrm{BB} / \mathrm{TB}(\mathrm{p}=0,089)$. Dan juga tidak terdapat hubungan antara pertambahan berat badan ibu trimester III kehamilan dengan pertumbuhan balita berdasarkan $B B / U(p=0,978)$, $\mathrm{TB} / \mathrm{U}(\mathrm{p}=0,678)$ dan $\mathrm{BB} / \mathrm{TB}(\mathrm{p}=0,724)$. Tidak terdapat hubungan antara riwayat status gizi ibu pada masa kehamilan berdasarkan ukuran LILA dan pertambahan berat badan ibu hamil trimester III dengan pertumbuhan anak balita.
\end{abstract}

Kata Kunci : Masa Kehamilan, Pertumbuhan Balita, Status Gizi

\section{Association Between History of Maternal Nutritional Status during Pregnancy with Growth of Under Five Year Children in Kecamatan Soreang Kabupaten Bandung}

\begin{abstract}
The growth of under-five children have a big impact for the next life of children because this period is known as critical or golden period. Children nutritional status need special attention not only at this time,but also since pregnancy. Maternal nutritional intake during pregnancy is important for fetal growth and newborn children's birth weight. Low birth weight is associated with increased risk of children growth problem with undernutrition, stunting and wasting. This study aimed to determine asscociation between maternal nutritional status during pregnancy based on mid-upper arm circumference and maternal weight gain in the third trimester with the growth of under-five year children. This study was conducted using analytical study with cross sectional design. Sample size were 109 mother and her under-five year children in sub-urban area, Kecamatan Soreang Kabupaten Bandung on March-November 2016. Sample size determination using multistage random sampling and analyzed by Gamma Chi-Square. This study was no association between maternal mid-upper arm circumference during pregnancy with growth of children under five years based on WAZ $(p=0,065), H A Z(p=0,218)$ and $W H Z(p=0,089)$. And also there was no association between maternal weight gain in the third trimester with growth of children under five years based on WAZ ( $p=0,978), H A Z(p-0,678)$, and WHZ $(p=0,724)$. There is no association between history of maternal nutritional status during pregnancy based on maternal mid-upper arm circumference and maternal weight gain in the third trimester with the growth of under-five children.
\end{abstract}

Keywords : Growth under five year children, Nutritional Status, Pregnancy

Korespondensi:

Ridha Mustika Zaif

Fakultas Kedokteran Universitas Padjadjaran

Jalan Raya Bandung-Sumedang Km. 21 Jatinangor, Sumedang

Mobile : 082153727217

Email : ridhamustika28@gmail.com 


\section{Pendahuluan}

Permasalahan gizi harus diperhatikan sejak masih dalam kandungan. ${ }^{1}$ Riwayat status gizi ibu hamil menjadi faktor penting terhadap pertumbuhan dan perkembangan janin. ${ }^{2}$ Jika terjadi kekurangan status gizi awal kehidupan maka akan berdampak terhadap kehidupan selanjutnya seperti Pertumbuhan Janin Terhambat (PJT), Berat Badan Lahir Rendah (BBLR), kecil, pendek kurus, daya tahan tubuh rendah dan risiko meninggal dunia. ${ }^{2,3}$

Anak dengan BBLR $(<2500$ gram) berpotensi besar mengalami status gizi kurang bahkan lebih buruk yang mempengaruhi kehidupannya termasuk risiko gangguan pertumbuhan., ${ }^{4,5}$ Akibatnya anak mengalami gagal tumbuh, postur tubuh kecil pendek yang ditandai dengan kegagalan mencapai tinggi dan berat badan ideal. ${ }^{6}$ Pertumbuhan anak balita juga dapat dipengaruhi oleh berbagai faktor. Tingkat pendidikan ibu yang rendah mempengaruhi pengetahuan tentang pola pengasuhan, perawatan, dan pemberian makan anak. Selain itu, ibu yang bekerja dapat meningkatkan kehidupan ekonomi keluarga sehingga mampu memberikan perhatianlayak bagi asupan gizi balita. ${ }^{7}$ Saat ini masalah pertumbuhan juga menjadi target international yang tercantum dalam SDGs (Sustainable Development Goals) untuk menurunkan angka kejadian anak balita pendek dan kurus sampai tahun $2025 .{ }^{8}$ Penelitian ini bertujuan untuk mengetahui hubungan antara status gizi ibu masa kehamilan yang dinilai dengan ukuran lingkar lengan atas (LILA) dan pertambahan berat badan ibu trimester III dengan pertumbuhan anak balita di daerah sub-urban Kecamatan Soreang, Kabupaten Bandung. Hasil penelitian ini agar dapat digunakan sebagai bahan evaluasi untuk meningkatkan kualitas status gizi ibu masa kehamilan dan menurunkan risiko gangguan pertumbuhan anak balita di masyarakat.

\section{Metode}

Penelitian ini merupakan penelitian analitik observasional korelatif dengan pendekatan cross sectional menggunakan data skala kategorik ordinal dengan variabel bebas yaitu data ukuran LILA dan pertambahan berat badan ibu trimester III saat hamil yang diambil dari data yang terdapat di dalam buku Kesehatan Ibu dan Anak (KIA). Variabel terikat yang digunakan yaitu pertumbuhan anak balita yang terdiri dari berat badan dan tinggi badan yang diperoleh dari hasil pengukuran menggunakan timbangan berat badan dengan presisi $0,1 \mathrm{~kg}$ dan alat ukur tinggi badan dengan presisi $0,1 \mathrm{~cm}$ yang diambil dalam waktu bersamaan. Penelitian ini dilakukan di Kecamatan Soreang, Kabupaten Bandung pada bulan Maret - November 2016 setelah mendapatkan persetujuan Komite Etik Penelitian Kesehatan Fakultas Kedokteran Universitas Padjajaran No. 48/UN6.C1.3.2/KEPK/ PN/2016.

Populasi penelitian adalah ibu yang memiliki balita yang berdomisili di Kecamatan Soreang, Kabupaten Bandung. Subjek penelitian adalah ibu yang memiliki anak balita di Kecamatan Soreang, Kabupaten Bandung setelah memenuhi kriteria inklusi yaitu, ibu yang memiliki anak balita yang berdomisili asli di Kecamatan Soreang, ibu yang memiliki buku KIA, dan ibu yang bersedia menjadi responden dan menandatangani lembar persetujuan (informed consent), serta tidak memenuhi kriteria ekslusi yaitu ibu dan anak balita yang memiliki riwayat penyakit kronik seperti TBC, hipertensi, gagal jantung, diabetes, kanker dan sebagainya.

Pengambilan sampel dengan metode probability sampling secara multistage random sampling. Tahap pertama memilih Kecamatan Soreang (daerah sub-urban) sebagai tempat penelitian, lalu dipilih 4 dari 10 desa secara acak yaitu desa Panyirapan, Sadu, Cingcin dan Soreang. Tahap kedua dipilih beberapa RW dari desa terpilih. Tahap selanjutnya melakukan pengambilan sampel secara acak. Besar sampel diketahui dengan menggunakan rumus analitik korelatif dengan ukuran sampel minimum sebesar 109.

Penelitian ini menggunakan data sekunder pertambahan berat badan selama trimester 3 dan ukuran LILA ibu saat hamil yang diambil dari catatan buku KIA ibu dan data primer berat dan tinggi badan balita yang diperoleh melalui hasil pengukuran saat penelitian dengan menggunakan timbangan berat badan dan alat ukur tinggi/ panjang badan. Pengolahan data dilakukan dengan menggunakan perangkat lunak pengolah data. Analisis data menggunakan uji statistik $C h i$ square untuk menguji signifikansi antar variabel dan uji Gamma untuk mengetahui kekuatan korelasi antar dua variabel. Tingkat signifikansi hasil uji $\mathrm{p}<0.05$ dan kekuatan korelasi $\mathrm{r}=-1$ sampai +1 . Sebelumnya dilakukan terlebih dahulu uji normalitas menggunakan One Sample Kolmogrov Smirnov Test dengan tarif signifikansi $5 \%$ dan data terdistribusi normal jika Sig. $>0,05$.

\section{Hasil}

Penelitian ini dilakukan untuk mengetahui hubungan riwayat status gizi ibu pada masa kehamilan dengan pertumbuhan anak balita yang dapat dilihat pada tabel 1 . 
Tabel 1 menunjukkan bahwa rata-rata pendidikan ibu yaitu dan tidak bekerja. Ukuran LILA ibu sebagian besar tidak KEK sebanyak $90(82,6 \%)$ ibu dan pertambahan berat badan ibu selama kehamilan trimester 3 sebagian besar kurang sebanyak $78(71,5 \%)$ ibu. Berdasarkan tabel 1 juga menunjukkan bahwa balita jenis kelamin lakilaki $63(57,8 \%)$ balita lebih banyak dibandingkan perempuan $46(42,2 \%)$ balita. Hampir semua balita lahir dengan berat badan normal $(>2.500$ gram) yaitu $101(92,7 \%)$ balita.

\section{Tabel 1 Distribusi Karakteristik Riwayat Ibu Masa Kehamilan dan Anak Balita}

\begin{tabular}{|c|c|c|}
\hline Karakteristik & Frekuensi (n) & Persentase (\%) \\
\hline \multicolumn{3}{|l|}{ Pendidikan Ibu } \\
\hline SD & 26 & 23,9 \\
\hline SMP & 45 & 41,3 \\
\hline SMA & 36 & 33,0 \\
\hline Perguruan Tinggi & 2 & 1,8 \\
\hline Total & 109 & 100,0 \\
\hline \multicolumn{3}{|l|}{ Pekerjaan Ibu } \\
\hline Tidak Bekerja & 74 & 67,9 \\
\hline Bekerja & 35 & 32,1 \\
\hline Total & 109 & 100,0 \\
\hline \multicolumn{3}{|l|}{ Ukuran LILA Ibu } \\
\hline $\mathrm{KEK}<23,5 \mathrm{~cm}$ & 19 & 17,4 \\
\hline Tidak KEK $>23,5 \mathrm{~cm}$ & 90 & 82,6 \\
\hline Total & 109 & 100,0 \\
\hline \multicolumn{3}{|c|}{ Penambahan berat badan Trimester 3 Ibu } \\
\hline Kurang $(<6$ kg) & 78 & 71,5 \\
\hline Cukup $(6-8 \mathrm{~kg})$ & 15 & 13,8 \\
\hline Lebih $(>8 \mathrm{~kg})$ & 16 & 14,7 \\
\hline Total & 109 & 100,0 \\
\hline \multicolumn{3}{|l|}{ Jenis Kelamin Balita } \\
\hline Laki-laki & 63 & 57,8 \\
\hline Perempuan & 46 & 42,2 \\
\hline Total & 109 & 100,0 \\
\hline \multicolumn{3}{|l|}{ Berat Bayi Lahir Balita } \\
\hline$<2.500$ gram & 8 & 7,3 \\
\hline$>2.500$ gram & 101 & 92,7 \\
\hline Total & 109 & 100,0 \\
\hline
\end{tabular}

Tabel 2 menunjukkan tidak terdapat hubungan yang signifikan antara ukuran LILA ibu pada masa kehamilan dengan berat bayi pada saat lahir di Kecamatan Soreang dengan perolehan nilai $\mathrm{p}=0,248(\mathrm{p}>0,05)$. Tetapi terdapat hubungan signifikan antara pertambahan berat badan ibu trimester III dengan berat bayi lahir dengan perolehan nilai $\mathrm{p}=0,004(\mathrm{p}<0,005)$ dengan korelasi positif dan kekuatan korelasi sempurna $\mathrm{r}=1,000$.
Tabel 3 menunjukkan bahwa hasil uji statistik Chi-Square dengan perolehan nilai $\mathrm{p}$ sebesar $0,065(\mathrm{p}>0,05)$, tidak terdapat hubungan antara ukuran LILA ibu masa kehamilan dengan pertumbuhan anak balita berdasarkan Z-score $\mathrm{BB} / \mathrm{U}$ dan juga tidak terdapat hubungan antara pertambahan berat badan ibu trimester III pada masa kehamilan dengan pertumbuhan anak balita berdasarkan Z-score BB/U di Kecamatan Soreang dengan nilai $p=0,978(p>0,05)$. 
Ridha Mustika Zaif : Hubungan antara Riwayat Status Gizi Ibu Masa Kehamilan dengan Pertumbuhan Anak Balita di Kecamatan Soreang Kabupaten Bandung

Tabel 2 Hubungan antara LILA dan Pertambahan Berat Badan Ibu Trimester III dengan Berat Lahir Bayi

\begin{tabular}{|c|c|c|c|c|c|}
\hline \multirow[b]{2}{*}{$\begin{array}{l}\text { Hubungan Riwayat Status } \\
\text { Gizi Ibu Masa Kehamilan }\end{array}$} & \multicolumn{2}{|c|}{ Berat Lahir } & \multirow[b]{2}{*}{ Total } & \multirow[b]{2}{*}{ Nilai $p$} & \multirow[b]{2}{*}{$\begin{array}{l}\text { K o e f i s i e } n \\
\text { Korelasi (r) }\end{array}$} \\
\hline & $\begin{array}{c}<2.500 \text { gram } \\
n \%\end{array}$ & $\begin{array}{c}>2.500 \text { gram } \\
n \%\end{array}$ & & & \\
\hline \multicolumn{6}{|l|}{ Ukuran LILA } \\
\hline KEK & $3(15,8 \%)$ & $16(84,2 \%)$ & $19(100,0 \%)$ & \multirow{3}{*}{0,248} & \multirow{3}{*}{0,522} \\
\hline Non KEK & $5(5,6 \%)$ & $85(94,4 \%)$ & $90(100,0 \%)$ & & \\
\hline Total & $8(7,3 \%)$ & $101(92,7 \%)$ & $109(100,0 \%)$ & & \\
\hline \multicolumn{6}{|l|}{$\begin{array}{l}\text { Pertambahan Berat Badan } \\
\text { Trimester III }\end{array}$} \\
\hline Kurang & $\begin{array}{c}8 \\
(10,3 \%)\end{array}$ & $\begin{array}{c}70 \\
(89,7 \%)\end{array}$ & $\begin{array}{c}78 \\
(100,0 \%)\end{array}$ & \multirow{4}{*}{0,004} & \multirow{4}{*}{1,000} \\
\hline Cukup & $\begin{array}{c}0 \\
(15,8 \%)\end{array}$ & $\begin{array}{c}15 \\
(100,0 \%)\end{array}$ & $\begin{array}{c}15 \\
(100,0 \%)\end{array}$ & & \\
\hline Lebih & $\begin{array}{c}0 \\
(5,6 \%)\end{array}$ & $\begin{array}{c}16 \\
(100,0 \%)\end{array}$ & $\begin{array}{c}16 \\
(100,0 \%)\end{array}$ & & \\
\hline Total & $\begin{array}{c}8 \\
(7,3 \%)\end{array}$ & $\begin{array}{c}101 \\
(92,7 \%)\end{array}$ & $\begin{array}{c}109 \\
(100,0 \%)\end{array}$ & & \\
\hline
\end{tabular}

Tabel 3 Hubungan Riwayat Status Gizi Ibu Selama Kehamilan dengan Pertumbuhan Anak Balita (BB/U)

\begin{tabular}{|c|c|c|c|c|c|c|c|}
\hline \multirow{3}{*}{$\begin{array}{l}\text { Riwayat Status } \\
\text { Gizi selama } \\
\text { Kehamilan }\end{array}$} & \multicolumn{4}{|c|}{ Pertumbuhan Anak Balita berdasarkan Z-score BB/U } & \multirow{3}{*}{ Total } & \multirow{3}{*}{ Nilai $\mathrm{p}$} & \multirow{3}{*}{$\begin{array}{c}\text { Koefisien } \\
\text { Korelasi } \\
\text { (r) }\end{array}$} \\
\hline & Buruk & Kurang & Baik & Lebih & & & \\
\hline & $\mathrm{n} \%$ & $\mathrm{n} \%$ & $\mathrm{n} \%$ & $\mathrm{n} \%$ & & & \\
\hline \multicolumn{8}{|l|}{ Ukuran LILA } \\
\hline KEK & $0(0,0 \%)$ & $1(5,3 \%)$ & $18(94,7 \%)$ & $0(0,0 \%)$ & $19(100 \%)$ & 0,065 & $-0,592$ \\
\hline Non KEK & $1(1,1 \%)$ & $15(16,7 \%)$ & $74(82,2 \%)$ & $0(0,0 \%)$ & $90(100 \%)$ & & \\
\hline Total & $1(0,9 \%)$ & $16(14,7 \%)$ & $92(84,4 \%)$ & $0(0,0 \%)$ & $109(100 \%)$ & & \\
\hline \multicolumn{8}{|l|}{$\begin{array}{l}\text { Pertambahan } \\
\text { Berat Badan } \\
\text { Trimester III }\end{array}$} \\
\hline Kurang & 1 & 11 & 66 & 0 & 78 & & \\
\hline$(<6 \mathrm{~kg})$ & $(1,3 \%)$ & $14,1 \%)$ & $(84,6 \%)$ & $(0,0 \%)$ & $(100,0 \%)$ & 0,978 & 0,007 \\
\hline Cukup & 0 & 3 & 12 & 0 & 15 & & \\
\hline$(6-8 \mathrm{~kg})$ & $(0,0 \%)$ & $(20,0 \%)$ & $(80,0 \%)$ & $(0,0 \%)$ & $(100,0 \%)$ & & \\
\hline Lebih & 0 & 2 & 14 & 0 & 16 & & \\
\hline$(>8 \mathrm{~kg})$ & $(0,0 \%)$ & $(12,5 \%)$ & $(87,5 \%)$ & $(0,0 \%)$ & $(100,0 \%)$ & & \\
\hline \multirow[t]{2}{*}{ Total } & 1 & 16 & 92 & 0 & 109 & & \\
\hline & $(0,9 \%)$ & $(14,7 \%)$ & $(84,4 \%)$ & $(0,0 \%$ & $(100,0 \%)$ & & \\
\hline
\end{tabular}


Ridha Mustika Zaif : Hubungan antara Riwayat Status Gizi Ibu Masa Kehamilan dengan Pertumbuhan Anak Balita di Kecamatan Soreang Kabupaten Bandung

Tabel 4 Hubungan Riwayat Status Gizi Ibu Selama Kehamilan dengan Pertumbuhan Anak Balita (TB/U)

\begin{tabular}{|c|c|c|c|c|c|c|c|}
\hline \multirow{3}{*}{$\begin{array}{l}\text { Riwayat Status } \\
\text { Gizi selama } \\
\text { Kehamilan }\end{array}$} & \multicolumn{4}{|c|}{ Pertumbuhan Anak Balita berdasarkan Z-score TB/U } & \multirow[t]{3}{*}{ Total } & \multirow[t]{3}{*}{ Nilai $p$} & \multirow{3}{*}{$\begin{array}{l}\text { Koefisien } \\
\text { Korelasi } \\
\text { (r) }\end{array}$} \\
\hline & Buruk & Kurang & Baik & Lebih & & & \\
\hline & $\mathrm{n} \%$ & $\mathrm{n} \%$ & $\mathrm{n} \%$ & $\mathrm{n} \%$ & & & \\
\hline \multicolumn{8}{|l|}{ Ukuran LILA } \\
\hline KEK & $2(10,5 \%)$ & $5(26,3 \%)$ & $11(57,9 \%)$ & $1(5,3 \%)$ & $19(100 \%)$ & 0,218 & $-0,259$ \\
\hline Non KEK & $17(1,1 \%)$ & $28(16,7 \%)$ & $43(82,2 \%)$ & $2(0,0 \%)$ & $90(100 \%)$ & & \\
\hline Total & $19(17,4 \%)$ & $33(30,3 \%)$ & $54(49,5 \%)$ & $3(2,8 \%)$ & $109(100 \%)$ & & \\
\hline \multicolumn{8}{|l|}{$\begin{array}{l}\text { Pertambahan } \\
\text { Berat Badan } \\
\text { Trimester III }\end{array}$} \\
\hline Kurang & 13 & 23 & 41 & 1 & 78 & & \\
\hline$(<6 \mathrm{~kg})$ & $(16,7 \%)$ & $(29,5) \%)$ & $(52,6 \%)$ & $(1,3 \%)$ & $(100,0 \%)$ & 0,678 & $-0,068$ \\
\hline Cukup & 2 & 5 & 6 & 2 & 15 & & \\
\hline$(6-8 \mathrm{~kg})$ & $(13,3 \%)$ & $(33,3 \%)$ & $(40,0 \%)$ & $(13,3 \%)$ & $(100,0 \%)$ & & \\
\hline Lebih & 4 & 5 & 7 & 0 & 16 & & \\
\hline$(>8 \mathrm{~kg})$ & $(25,0 \%)$ & $(31,2 \%)$ & $(43,8 \%)$ & $(0,0 \%)$ & $(100,0 \%)$ & & \\
\hline \multirow[t]{2}{*}{ Total } & 19 & 33 & 34 & 3 & 109 & & \\
\hline & $(17,4 \%)$ & $(30,3 \%)$ & $(49,5 \%)$ & $(2,8 \%)$ & $(100,0 \%)$ & & \\
\hline
\end{tabular}

Tabel 5 Hubungan Riwayat Status Gizi Ibu Selama Kehamilan dengan Pertumbuhan Anak Balita (BB/TB)

\begin{tabular}{|c|c|c|c|c|c|c|c|}
\hline \multirow{3}{*}{$\begin{array}{l}\text { Riwayat Status } \\
\text { Gizi selama } \\
\text { Kehamilan }\end{array}$} & \multicolumn{4}{|c|}{ Pertumbuhan Anak Balita berdasarkan Z-score BB/TB } & \multirow[t]{3}{*}{ Total } & \multirow[t]{3}{*}{ Nilai $\mathrm{p}$} & \multirow{3}{*}{$\begin{array}{l}\text { Koefisien } \\
\text { Korelasi } \\
\text { (r) }\end{array}$} \\
\hline & Buruk & Kurang & Baik & Lebih & & & \\
\hline & $\mathrm{n} \%$ & $\mathrm{n} \%$ & $\mathrm{n} \%$ & $\mathrm{n} \%$ & & & \\
\hline \multicolumn{8}{|l|}{ Ukuran LILA } \\
\hline KEK & $0(0,0 \%)$ & $1(5,3 \%)$ & $15(57,9 \%)$ & $3(15,8 \%)$ & $19(100 \%)$ & 0,869 & $-0,052$ \\
\hline Non KEK & $1(1,1 \%)$ & $3(3,3 \%)$ & $74(82,2 \%)$ & $12(13,3 \%)$ & $90(100 \%)$ & & \\
\hline Total & $1(0,9 \%)$ & $4(3,7 \%)$ & $89(81,7 \%)$ & $15(13,8 \%)$ & $109(100 \%)$ & & \\
\hline \multicolumn{8}{|l|}{$\begin{array}{l}\text { Pertambahan } \\
\text { Berat Badan } \\
\text { Trimester III }\end{array}$} \\
\hline Kurang & 1 & 1 & 65 & 11 & 78 & & \\
\hline$(<6 \mathrm{~kg})$ & $(1,3 \%)$ & $(1,3) \%$ & $(83,3 \%)$ & $(14,1 \%)$ & $(100,0 \%)$ & 0,724 & $-0,085$ \\
\hline Cukup & 0 & 3 & 12 & 0 & 15 & & \\
\hline$(6-8 \mathrm{~kg})$ & $(0,0 \%)$ & $(20,0 \%)$ & $(80,0 \%)$ & $(0,0 \%)$ & $(100,0 \%)$ & & \\
\hline Lebih & 0 & 0 & 12 & 4 & 16 & & \\
\hline$(>8 \mathrm{~kg})$ & $(0,0 \%)$ & $(0,0 \%)$ & $(43,8 \%)$ & $(75,0 \%)$ & $(100,0 \%)$ & & \\
\hline Total & $\begin{array}{c}1 \\
(0,9 \%)\end{array}$ & $\begin{array}{c}4 \\
(3,7 \%)\end{array}$ & $\begin{array}{c}89 \\
(81,7 \%)\end{array}$ & $\begin{array}{c}15 \\
(13,8 \%)\end{array}$ & $\begin{array}{c}109 \\
(100,0 \%)\end{array}$ & & \\
\hline
\end{tabular}


Tabel 4 menunjukkan bahwa tidak terdapat hubungan yang bermakna antara ukuran LILA ibu pada masa kehamilan dengan pertumbuhan anak balita berdasarkan Z-score TB/U dengan perolehan nilai $\mathrm{p}=0,218(\mathrm{p}>0,05)$. Selain itu, hasil analisis ini juga menunjukkan bahwa tidak terdapat hubungan yang bermakna antara pertambahan berat badan trimester III masa kehamilan dengan pertumbuhan balita berdasarkan Z-score TB/U dengan nilai $\mathrm{p}=0,678$ $(\mathrm{p}>0,05)$.

Tabel 5 menunjukkan bahwa tidak terdapat hubungan yang signifikan antara ukuran LILA ibu masa kehamilan dengan pertumbuhan anak balita berdasarkan $\mathrm{BB} / \mathrm{TB}$ dengan nilai $\mathrm{p}=0,089$ $(\mathrm{p}>0,05)$. Dan juga tidak terdapat hubungan antara pertambahan berat badan ibu trimester 3 kehamilan dengan pertumbuhan anak balita berdasarkan $\mathrm{BB} / \mathrm{TB}$ denga nilai $\mathrm{p}=0,724(\mathrm{p}>$ $0,05)$. Analisis selanjutnya menentukan hubungan status gizi ibu masa kehamilan dengan berat bayi pada saat hamil untuk mengetahui hubungan variabel perancu (pendidikan dan pekerjaan ibu) dengan pertumbuhan anak balita secara umum.

Tabel 6 menunjukkan bahwa pendidikan dan pekerjaan ibu tidak terdapat hubungan dengan pertumbuhan anak balita dan bukan menjadi variabel perancu dalam hasil penelitian ini $(p$ $>0,005)$.

\section{Pembahasan}

Penelitian ini dilakukan pada 109 orang ibu yang mempunyai anak balita di Kecamatan
Soreang Kabupaten Bandung. Anak balita berjenis kelamin laki-laki sebanyak 63 orang dan berjenis perempuan sebanyak 46 orang. Status gizi ibu hamil dapat dinilai diantaranya dengan pengukuran Lingkar Lengan Atas (LILA) dan pertambahan berat badan selama kehamilan terutama pada trimester II dan III karena pada trimester ini terjadi perubahan yang lebih signifikan. ${ }^{4,5}$ Pada penelitian ini data pertambahan berat badan yang dianalisis yaitu data selama trimester III kehamilan.

Data dianalisis menggunakan uji bivariat untuk mengetahui hubungan antara berat lahir bayi dengan pertumbuhan anak balita berdasarkan klasifikasi Z-score. Peneliti tidak menemukan penelitian sebelumnya yang mendukung hasil penelitian ini secara langsung. Namun, terdapat beberapa penelitian sebelumnya yang dilakukan untuk mengetahui hubungan antara status gizi ibu pada masa kehamilan dengan berat lahir bayi dan beberapa penelitian sebelumnya yang dilakukan untuk mengetahui hubungan berat bayi lahir dengan status gizi pada anak balita.

Hasil dari analisis data menunjukkan bahwa tidak terdapat hubungan antara ukuran LILA ibu pada saat hamil dengan berat bayi lahir di Kecamatan Soreang Kabupaten Bandung. Hasil penelitian berbeda dengan penelitian yang dilakukan oleh Linda di Puskesmas Tanjung Karang Tahun 2012 yang menyatakan bahwa ada hubungan yang bermakna antara LILA dengan berat badan bayi baru lahir. ${ }^{9}$ Hal ini juga berbeda dengan penelitian dari Eny Pemilu mengenai hubungan umur dan KEK terhadap berat lahir bayi bahwa ibu yang hamil dalam keadaan KEK

Tabel 6 Hubungan antara Karakteristik Ibu dengan Pertumbuhan Anak Balita secara Umum

\begin{tabular}{|c|c|c|c|c|c|c|c|}
\hline \multirow{3}{*}{ Karakteristik } & \multicolumn{4}{|c|}{ Pertumbuhan Anak Balita } & \multirow[t]{3}{*}{ Total } & \multirow{3}{*}{$\begin{array}{c}\text { Nilai } \\
\text { p }\end{array}$} & \multirow{3}{*}{$\begin{array}{l}\text { Koefisien } \\
\text { Korelasi } \\
\quad(\mathrm{r})\end{array}$} \\
\hline & Buruk & Kurang & Baik & Lebih & & & \\
\hline & $\mathrm{n} \%$ & $\mathrm{n} \%$ & $\mathrm{n} \%$ & $\mathrm{n} \%$ & & & \\
\hline \multicolumn{8}{|l|}{ Pendidikan } \\
\hline SD & $1(3,8 \%)$ & $3(11,5 \%)$ & $22(84,6 \%)$ & $0(0 \%)$ & $26(100 \%)$ & & \\
\hline SMP & $0(0,0 \%)$ & $6(13,3 \%)$ & $39(86,7 \%)$ & $0(0,0 \%)$ & $45(100 \%)$ & & \\
\hline SMA & $0(0,0 \%)$ & $7(19,4 \%)$ & $29(80,6 \%)$ & $0(0,0 \%)$ & $36(100 \%)$ & 0,775 & $-0,063$ \\
\hline Perguruan tinggi & $0(0, \% 0)$ & $0(0,0 \%)$ & $2(100,0 \%)$ & $0(0,0 \%)$ & $2(100 \%)$ & & \\
\hline Total & $1(0,9 \%)$ & $16(14,7 \%)$ & $92(84,4 \%)$ & $0(0,0 \%)$ & $109(100 \%)$ & & \\
\hline$(<6 \mathrm{~kg})$ & $(1,3 \%)$ & $(1,3) \%$ & $(83,3 \%)$ & $(14,1 \%)$ & $(100,0 \%)$ & & \\
\hline \multicolumn{8}{|l|}{ Pekerjaan } \\
\hline Tidak Bekerja & $1(1,4 \%)$ & $9(12,2 \%)$ & $64(86,5 \%)$ & $0(0,0 \%)$ & $74(100 \%)$ & 0,427 & $-0,219$ \\
\hline Bekerja & $0(0,0 \%)$ & $7(20,0 \%)$ & $28(80,0 \%)$ & $0(100,0 \%)$ & $35(100 \%)$ & & \\
\hline Total & $1(0,9 \%)$ & $16(14,7 \%)$ & $92(84,4 \%)$ & $0(84,4 \%)$ & $109(100,0 \%)$ & & \\
\hline
\end{tabular}


cenderung melahirkan bayi dengan BBLR. $^{4}$ Adanya perbedaan ini mungkin disebabkan oleh berbagai faktor seperti umur yang tidak aman, asupan energi (protein dan lemak), tingkat pendidikan, status pekerjaan, pendapatan, umur kehamilan dan kadar haemoglobin dalam darah serta konsumsi pil besi. ${ }^{10,11}$

Terdapat hubungan yang signifikan antara pertambahan berat badan ibu selama trimester III dengan berat lahir bayi. Hasil ini sesuai dengan teori yang menyatakan bahwa pertambahan berat badan terutama trimester II dan III yang merupakan pertambahan berat badan yang paling signifikan selama masa kehamilan dapat mempengaruhi berat lahir bayi. ${ }^{4,5}$ Tetapi berbeda dengan penelitian yang dilakukan oleh Hasmeinda di Kabupaten Semarang pada tahun 2012 dan Michele Drehmer dkk. bahwa penambahan berat badan selama trimester III tidak mempengaruhi keadaan bayi saat lahir tetapi penambahan berat badan yang dianjurkan selama trimester II dan III dapat mempengaruhi kondisi bayi saat lahir. ${ }^{1213}$

Tidak terdapat hubungan antara berat lahir bayi dan status gizi termasuk pertumbuhan balita. Hasil ini sesuai dengan penelitian Eka Pratandianan dkk. mengenai hubungan status gizi dan berat lahir pada anak usia 2-3 tahun menunjukkan bahwa tidak terdapat hubungan antara status gizi dan berat lahir. ${ }^{14}$ Penelitian ini juga sesuai dengan yang dilakukan oleh Mikhael Tonda dkk. mengenai hubungan status gizi saat lahir dengan pertumbuhan balita saat ini di Desa Caturtunggal Kecamatan Depok Sleman Yogyakarta bahwa tidak terdapat hubungan berat bayi lahir dengan pertumbuham balita saat ini. ${ }^{6}$

Selanjutnya dilakukan analisis bivariat dengan menggunakan Gamma Chi-square untuk mengetahui hubungan yang signifikan antara riwayat status gizi ibu pada masa kehamilan (ukuran LILA dan pertambahan berat badan trimester III) dan pertumbuhan anak balita berdasarkan berat badan terhadap umur, tinggi badan terhadap umur serta berat badan terhadap tinggi badan di daerah suburban Kecamatan Soreang Kabupaten Bandung.

Hasil yang diperoleh sama dengan penelitian sebelumnya bahwa tidak terdapat hubungan yang signifikan antara riwayat status gizi ibu masa kehamilan (ukuran LILA dan pertambahan berat badan trimeseter III) dengan pertumbuhan anak balita. Namun, riwayat status gizi ibu mempunyai hubungan yang signifikan dengan status gizi dan berat lahir bayi. Hal ini mungkin dipengaruhi oleh berbagai faktor. Adapun faktor-faktor yang dapat mempengaruhi status gizi anak balita yaitu kondisi sosial ekonomi. Berbagai penelitian menunjukkan telah terjadi peningkatan kasus gizi kurang yang berdampak terhadap pertumbuhan anak balita yang disebabkan oleh kondisi ekonomi keluarga (orang tua). Kemiskinan berkaitan erat dengan pertumbuhan anak balita, sehingga peningkatan gizi termasuk pertumbuhan balita harus diiringi dengan upaya peningkatan ekonomi. Bukan hanya itu, pendidikan ibu, pekerjaan ibu, pendapatan keluarga, jumlah anak, pola asuh dan riwayat penyakit infeksi juga mempengaruhi status gizi termasuk pertumbuhan anak balita. ${ }^{7,15}$

Selain itu, faktor lain yang dapat mempengaruhi pertumbuhan balita adalah jenis pekerjaan ayah dan jenis pekerjaan ibu. Jenis pekerjaan yang sebagian besar mejadi buruh maka diperkirakan pendapatan keluarga rendah, sehingga akan berpengaruh terhdap pemilihan bahan makanan dan akan mempengaruhi status gizi dan pertumbuhan balita. ${ }^{1}$

Kemudian dilakukan uji analisis terhadap faktor-faktor yang dapat mempengaruhi status gizi anak balita. Tidak terdapat hubungan yang signifikan antara pendidikan dan pekerjaan ibu dengan pertumbuhan anak balita. Hal ini sesuai dengan penelitian yang dilakukan oleh Dian Kholika Hamal menegenai hubungan pendidikan dan pekerjaan orangtua serta pola asuh dengan status gizi balita di kota dan kabupaten Tangerang tidak menunjukkan adanya hubungan yang bermakna dengan status gizi balita termasuk pertumbuhan. ${ }^{16}$

Keterbatasan penelitian yaitu tidak lengkapnya data pertambahan berat badan setiap trimester yang disebabkan karena beberapa orang tua tidak rutin memeriksakan kehamilannya setiap bulan kepada bidan dan pada saat posyandu, rata-rata ibu hamil baru rutin memeriksakan kehamilannya saat trimester III. Selain itu faktor rusak dan hilangnya buku KIA juga menjadi kendala dalam penelitian ini. Sehingga penelitian ini tidak melihat hubungan pertambahan berat badan berdasarkan Indeks Massa Tubuh selama kehamilan. Selain banyaknya keterbatasan penelitian ini tidak diikutsertakan variabel atau faktor lain yang dapat mempengaruhi status gizi anak balita sebagai variabel perancu.

Berdasarkan hasil penelitian ini dapat disimpulkan bahwa tidak terdapat hubungan yang signifikan antara riwayat status gizi ibu pada masa kehamilan berdasarkan ukuran LILA dan pertambahan berat badan trimester III dengan pertumbuhan balita. Perlu diadakan penelitian selanjutnya dengan memperhatikan faktor-faktor lain seperti kondisi sosial ekonomi yang mempengaruhi pertumbuhan anak balita. Ibu pada masa kehamilan perlu diberi edukasi mengenai faktor lain yang dapat mempengaruhi pertumbuhan anak balita selain berat bayi lahir. 


\section{Daftar Pustaka}

1. Devi M. Analisis Faktor-Faktor yang Berpengaruh terhadap Status Gizi Balita di Pedesaan. Teknologi dan Kejuruan. 2010;33(2):183-192.

2. Yongky, Hardiansyah, Gulardi, Marhamah. Status Gizi Awal Kehamilan dan Pertambahan Berat Badan Ibu Hamil Kaitannya dengan BBLR. Jurnal Gizi dan Pangan. 2009;4(1):812.

3. Kementerian Kesehatan Republik Indonesia. Status Gizi Pengaruhi Kualitas Bangsa. Jakarta: Kementerian Kesehatan RI. 2015;20-21.

4. Kusparlina EP. Hubungan antara Umur dan Status Gizi Ibu Berdasarkan Ukuran Lingkar Lengan Atas dengan Jenis BBLR. Jurnal Penelitian Kesehatan Suara Forikes. 2016;7(1):8-13.

5. Shiddiq A, Lipoeto NI. Artikel Penelitian Hubungan Pertambahan Berat Badan Ibu Hamil terhadap Berat Bayi Lahir di Kota Pariaman. Jurnal Fk Unand.2011;3(1):472-7.

6. Tonda M. Hubungan Status Gizi Saat Lahir Dengan Pertumbuhan Balita Saat Ini di Desa Caturtunggal Kecamatan Depok Sleman Yogyakarta. 2012;1-10.

7. Putri RF, Sulastri D, Lestari Y. Faktor-Faktor yang Berhubungan dengan Status Gizi Anak Balita di Wilayah Kerja Puskesmas Nanggalo Padang. 2015. 4:254-261.

8. Rakorpop Kementerian Kesehatan Republik Indonesia. Kesehatan dalam Kerangka Sustainable Development Goals (SDGs). Jakarta: Kementerian Kesehatan RI; 2015.

9. Linda. Hubungan Pertambahan Berat Badan dan Ukuran Lingkar Lengat Atas Ibu Selama Kehamilan dengan Berat Badan Bayi Baru Lahir di Wilayah Kerja Puskesmas Tanjung Karang Tahun 2012. Media Bina Ilmiah. 2014;8(1):30-34.

10. Mahirawati VK. Faktor-Faktor yang Berhubungan dengan Kekurangan Energi Kronis (KEK) pada Ibu Hamil di Kecamatan Kamoning dan Tembelangan, Kabupaten Sampang, Jawa Timur. Buletin Penelitian Kesehatan. 2014;17(1):193-202.

11. Ausa ES, Jafar N, Indriasari R. Hubungan Pola Makan dan Status Sosial Ekonomi dengan Kejadian KEK pada Ibu Hamil di Kabupaten Gowa Tahun 2013. 2013;2-14.

12. Marindratama H. Hubungan Pertambahan Berat Badan Ibu Hamil Trimester III dengan Berat Bayi Lahir di Kabupaten Semarang. 2014.

13. Drehmer M, Duncan BB, Kac G, Schmidt MI. Association of Second and Third Trimester Weight Gain in Pregnancy with Maternal Fetal Outcomes. Plos One. 2013;8(1).

14. Patandianan E, Umboh A, Warouw S. Hubungan Status Gii dengan Berat Lahir pada Anak Usia 2-3 Tahun. Jurnal E-Clinic (eCl). 2015;3(1):1-6.

15. Gea-horta T, Felisbino-mendes MS, Joel R, Ortiz F, Velasquez-melendez G. Association Between Maternal Socioeconomic Factors and Nutritional Outcomes in Children Under 5 Years of Age. J Pediatr (Rio J). Sociedade Brasileira de Pediatria; 2016;92(6):574-80.

16. Hamal DK, Linda O. Hubungan Pendidikan dan Pekerjaan Orangtua serta Pola Asuh dengan Status Gizi Balita di Kota dan Kabupaten Tangerang, Banten. 2011;134-41. 